\title{
Mediating Role of Customer Satisfaction between Corporate Social Responsibility and Customer-Based Brand Equity
}

\begin{abstract}
Khurram Shahzad ${ }^{1}$, Ifzal Ahmad ${ }^{2}$, Asma Gul ${ }^{3}$
Abstract

Using expectation conformation theory, this study theorized and empirically tested the relationship between corporate social responsibility (CSR) and customer-based brand equity via customer satisfaction. Data were collected from 225 customers of well-known brands of consumer goods and services using survey questionnaire consisting of standardized scales. Regression analysis using Baron and Kenney (1986) approach via SPSS was utilized to test the proposed hypotheses. Results confirm direct relationship between CSR and customer satisfaction and CSR and customer-based brand equity as well as direct effect of customer satisfaction on customer-based brand equity. In addition, the study also found support for mediating effect of customer satisfaction in relationship of CSR and customer-based brand equity. Importance of CSR activities, its awareness and communication are some of managerial implications of this study. Limitations of the study coupled with future directions have been highlighted.
\end{abstract}

Keywords: Corporate social responsibility; Customer-based brand equity; Customer satisfaction; Expectation-confirmation theory; Pakistan

\section{Introduction}

In the past couple of decades, the notion of Corporate Social Responsibility (CSR) has gained more attention as a result of the large scale corporate scandals and malpractices around the world. Resultantly, organizations are expected to behave responsibly and take care of all the stakeholders instead of focusing on a single one i.e. shareholders (Ahmad, 2017). Responding affirmatively to such calls from various societal pressure groups, organizations have massively embarked upon social initiatives (van Rekom, Berens, \& van Halderen, 2013) in anticipation of appreciation from shareholders, customers, employees, suppliers and NGOs (Gatti, Caruana, \& Shenota, 2012) etc. Due to this fact, CSR has gained vital importance and is now

1 Professor, Riphah International University.e-mail: kshahzad78@yahoo.com

2 Assistant Professor, Karakoram International University, Gilgit. e-mail: ifzalmdn@gmail.com

3 Lecturer, Riphah International University, Islamabad, Pakistan. e-mail: asmagul87@yhaoo.com

\begin{tabular}{ll} 
ARTICLE HISTORY & \\
5 Apr, 2018 Submission Received & 2 Nov, 2018 First Review \\
\hline 7 Jan, 2019 Second Review & 20 Feb, 2019 Third Review \\
\hline 2 Mar, 2019 Accepted &
\end{tabular}


seen as a key component of organization's ethical behavior (Luetkenhorst, 2004). With wide awareness of the term, the concept of CSR is now not just limited to philanthropic activities (Carroll, 1991) but it is also viewed as a responsible, ethical and a smart approach of conducting business considering its effects on the surrounding environment, stakeholders and the society as a whole.

Among the stakeholders, customers are the element of key concern for the companies because being profit generating entities, customers' satisfaction and strong relationships are vital for its sustainable growth (Economist, 20084; Miller \& Merrilees, 2013). Apart from being a key stakeholder, customers have more knowledge about the company's products and services and therefore, can play an important role in establishing the company's reputation (Ferrell, 2004). Furthermore, they not only have increased awareness about the activities of companies but they also evaluate the practices of the companies in a sense that they are aware about the importance of environmental issues, ethics, and other social responsibilities thereby affecting purchase and consumption of products (Ferrell, 2004). Studies suggest that buyers have become more conscious about the responsible business practices of the companies to the extent that they are willing to pay even higher prices for products of socially responsible firms (Guzman \& Davis, 2017; Rayapura, 2014).

Depending on the importance of CSR, there is a stream of research that highlights important outcomes of investing in socially responsible initiatives. For example, investment in CSR activities lead the companies toward favorable stakeholders' attitudes and behaviors (i.e. purchase intentions, investment in company and employment seeking behavior) as well as enhance the company's brand image, strengthens relationships and increase advocacy behavior including word of mouth, employee citizenship behavior and commitment (Du, Bhattacharya, \& Sen, 2010). Furthermore, CSR activities increase financial performance of the company (McGuire, Sundgren, \& Schneeweis, 1988), firm performance (Kiessling, Isaksson \& Yasar, 2016), congruence of costumer with company (Sen \& Bhattacharya, 2001), customer's trust and loyalty with brand and company (Perez \& del Bosque, 2015; Walsh \& Bartikowski, 2012) as well as favorable customer attitude and behaviors towards products of that company (Brown, 1998).

Among many outcomes, brand equity is also an important outcome of CSR activities and many studies in past have reported a relationship between CSR and brand equity (Hur, Kim \& Woo, 2014; Lai, Chiu, Yang, \& Pai, 2010; Wang, 2010); however, there is a limited understanding of the underlying mechanism through which socially responsible actions have an effect on customer-based brand equity - a key gap (i.e. the underlying mechanisms through which CSR leads to outcomes) in the extant literature worth exploring (Glavas, 2016; Deng \& Xu, 2017). Hur et al. (2014)

4 Economist (2008). Just good business. Special report on CSR. January, 19th. 
studied the mediating role of corporate brand credibility and reputation; however, they suggest that other mediating mechanisms must also be explored to extend its full understanding in a different cross-national context. Likewise, Fatima, Rahman and Khan (2015) studied the mediating role of trust between CSR and brand-equity. They too recommended other mediating variables (such as customer satisfaction) among the two variables. Customer satisfaction can be seen as an evaluative tool of CSR as to what customer holds and believes about the company, will translate into their attitudes towards products and services offered by the company (Luo \& Bhattacharya, 2006; Brown \& Dacin, 1997). Customer satisfaction has been used in the past as a mediator between social associations and other forms of behavioral outcomes like loyalty and positive customer word of mouth (e.g. Salmones, Crespo \& del Bosque, 2005; Walsh $\&$ Bartikowski, 2012). Therefore, this study argues that there is a potential mediating role of customer satisfaction between CSR and customers' brand-equity also.

This study thus fills this knowledge gap by doing an investigation on the mediating role of customer satisfaction on CSR-Brand equity relationship. We draw upon the expectation-confirmation theory (Oliver, 1980) to argue that fulfillment of customer's expectations regarding social performance of firm can be one of the mechanisms that will translate firm's social initiatives into a source of generating customer-based brand equity. This study contributes to the existing body of knowledge in three distinct ways. First contribution is the investigation of CSR's effect on customer satisfaction and brand equity. Second, this study tests the mediating role of customer satisfaction between CSR and brand equity. Third, our study incorporates contextual novelty by conducting research in a developing country i.e. Pakistan. Most of researches on the topic of CSR in relation customer's outcomes have been done in western settings where most countries are developed. Little evidence is available about generalizability of their findings in underdeveloped and developing countries of eastern world like Pakistan.

Developing countries like Pakistan have recently received attention on the issue of CSR however they are unaware of its diverse implications on businesses (Khan, 2012). The Securities and Exchange Commission of Pakistan (SECP, 2013) has also necessitated the listed companies to issue their CSR reports for the general public. Likewise, other societal organizations such Responsible Business Initiatives (RBI), Pakistan Center for Philanthropy (PCP), Corporate Social Responsibility Center, Pakistan and National Forum for Environment and Health etc. are also advocating for CSR (Ahmad, 2017). Consequently, many of the well-known brands seem to have engaged in promoting and advertising their CSR actions. However, little empirical research evidence is available on the relationship between CSR and outcomes, particularly from customers' perspective in Pakistan. Furthermore, Drazin and Schoonhoven (1996) also pointed out that most of the empirical research in organization science has 
focused on North American organizations which raise the question of generalizability of current theories in organizations in outside North American context.

Therefore, this study is aimed to investigate the following objectives:

1. To study the direct impact of corporate social responsibility on customer-based brand equity.

2. To study the direct impact of corporate social responsibility on customer satisfaction.

3. To study the direct impact of customer satisfaction on customer-based brand equity.

4. To study the mediating role of customer satisfaction between corporate social responsibility and customer-based brand equity.

5. To bring evidence from a developing country's perspective i.e. data collection from Pakistan based organization.

\section{Literature Review}

\subsection{Corporate social responsibility}

In current world's dynamic and intensely competitive environment, success of any organization depends upon effective strategy making and its implementation. The concept of CSR has become an area of huge strategic importance (Luo \&

Bhattacharya, 2006). Companies today face immense pressure to act in a responsible manner to report social performance, publish CSR statements and code of ethics, in order to show their commitment towards various stakeholders (Ahmad, 2017). The companies have to justify that their existence is valuable not only for their stakeholders but for the society as a whole. Significance of CSR is also evident from the considerable involvement of companies in social programming and explicit activities taken by many multinational companies for sustainable development. They not only invest in social initiatives but also make an effort to communicate these actions to their stakeholders (Sen, Du, \& Bhattacharya, 2016).

Terms such as corporate conscience, corporate citizenship, responsible business and social performance are often interchangeably used for CSR (Wood, 1991). All these terms reflect the clearly expressed and communicated policies and practices of a company showing responsibility of business for betterment of society as a whole (Matten \& Moon, 2008). In addition, CSR is "the company's status and activities with 
respect to its perceived societal obligations" (Brown \& Dacin, 1997: 68). According to Lai and colleagues (2010), CSR are the voluntary activities initiated by companies to increase social, economic and environmental performance or "CSR activities are the responsibilities of corporations towards the society within which they are working" (Narwal \& Singh, 2013, p. 465). CSR includes situations in which organizations do not merely think of compliance with environmental policies and government's laws and regulations, rather, they go beyond the compliance and proactively indulge in activities which resolves social ills (McWilliams Siegel, \& Wright, 2006).

\subsection{Customer-based brand equity}

Brand equity is an essential element for marketers of consumer goods and services (Lassar, Mittal, \& Sharma, 1995). It is "the incremental utility or value added to a product by its brand name" (Yoo \& Donthu, 2001. p. 1). It refers to the degree to which difference in quality, image, status and reliability of a branded product are perceived in comparison to that of non-branded product (Swait, Erdem, Louviere \& Dubelaar, 1993). This study focuses on customer-based brand equity measurement which refers to the extent of customers' familiarity with the brand, favorable and unique association that they have in their mind regarding that brand (Keller, 1993). Customer-based measure of brand equity thus defines customer's knowledge, attitude, behavior, association and perception towards a particular brand. It assesses brand equity using several important brand attributes and dimensions therefore, has more potential diagnostic abilities than the other measures.

Furthermore, customer-based brand equity has five dimensions i.e. brand awareness, brand association, perceived quality, brand loyalty and propriety brand asset (Aaker, 1991). However, most of the previous studies have not used propriety brand asset in their measures therefore, this research also favors the other four dimensions (cf. Lai et al. 2010). Over the years, different researches have proposed various dimensions for brand equity but all of the models have one or more components of Aaker's dimensions common in them as these components are best known to capture the customer's behavior in relation to brand equity. Brand awareness refers to how easily a brand is recognized to be belonging to a particular category of product. Brand associations are the links and affiliations that form brand memory (Aaker, 1991). Perceived quality refers to the judgement of consumer about a particular brand on grounds of excellence and superiority over others (Zeithaml, 1988) and brand loyalty means feeling(s) of attachment towards a focal brand and a tendency to engage in repeat purchase (Aaker, 1991; Yoo \& Donthu, 2001). Although brand equity is multidimensional in its nature, we treat it as a holistic construct in our study as has been done in previous studies (e.g. Lai et al. 2010). 


\subsection{Customer satisfaction}

Satisfaction is a psychological state that evaluates whether the consumer experience with the particular product/service meets their expectations and needs (Oliver, 1997; Zeithaml \& Bitner, 2000). It reflects their fulfillment response and results in an attitude change towards the product/service. One of the important component of corporate strategy is customer satisfaction as long term profitability of any organization is dependent on it (Gruca \& Rego, 2005) and satisfied stakeholders (e.g. customers) are a source of generating valuable intangible resources for a firm (Blumenthal \& Bergstorm, 2003). When customers are satisfied from a product or service they develop favorable behavioral intentions to maintain that level of satisfaction (Hsu, 2012). Among the behavioral outcomes of the customer satisfaction are word of mouth, repurchase intentions (Brady \& Robertson, 2001), customer commitment and loyalty (Donio et al. 2006).

\subsection{Expectation-confirmation theory}

The expectation-confirmation theory (ECT) is very simple in its nature. Before the start of an event, a person has some expectations. If those expectations are met or exceed, the person will be satisfied. However, if those expectations are unmet or below the standards, the person will not be satisfied. For example, if a customer buys a television and his performance expectations from the company's product and services are met, the customer will be satisfied. However, if the quality of product or service is below the perceived standards, the customer will not be satisfied. ECT has been used for many decades by military experts believing the fulfillment of expectations lead to high morale (Spector, 1956), however, the more current concept of this theory is related to Oliver (1980).

According to Oliver (1980), there are four main constructs of the ECT i.e. expectations, performance, disconfirmation, and satisfaction. Expectations are the comparisons or standards used for evaluation of performance (Halstead, 1999). Performance is the assessment of product after its usage. Resultantly, if the performance meets the expectations of an individual (confirmation), it will result in satisfaction. However, if a product falls short of its expectations, disconfirmation will occur and will result in dissatisfaction (Oliver, 1980). According to ECT, satisfaction is an antecedent which will lead to impact other outcomes. As shown in Figure 1, our proposed model includes customer satisfaction is an antecedent of corporate social responsibility which leads to customer-based brand equity. Hence, we believe that ECT will be an appropriate theory for exploring the impact of corporate social responsibility on customer-based brand equity while using customer satisfaction as mediator. 


\section{Hypotheses Development}

\subsection{CSR and customer-based brand equity}

What customers hear, learn, see and feel about the brand form its differential effect, therefore, brand power resides in the mind of the customers. In fact, CSR serves as a way to differentiate brands from others (Holt, Quelch, \& Taylor, 2004) by improving firm's reputation (Torres, Bijmolt, Tribo, \& Verhoef, 2012) and generating a good image which leads to loyal customers having positive association with the brand based on the perceived quality. The way in which CSR marks itself helps to establish customer support (Green \& Peloza, 2011). In this regard, past studies have acknowledged a positive relationship between CSR and customer based outcomes such as loyalty, brand preferences and brand perceptions (Rust, Zeithaml, \& Lemon, 2000; Bhattacharya \& Sen, 2004). CSR and corporate associations have been reported to generate positive behavioral outcomes such as loyalty (Walsh \& Bartikowski, 2012). CSR positively affects industrial brand equity and brand performance (Lai et al. 2010). CSR also contributes towards increasing market value (stock-performance), brand associations, brand identity and loyalty (Walsh \& Bartikowski, 2012; Luo \& Bhattacharya, 2006). As CSR initiatives differentiate a company's products and services by generating a good image and reputation, these initiatives lead the company towards brand equity (Hsu, 2012). In the same way, Wang (2010) also confirmed that financial-based brand equity of any organization is affected by social performance. Therefore, for building strong relationships, brand managers have to ensure that the customers have a good experience with all the aspects of brands. Studies found that customers expect that the companies must be responsible in their business practices, engage in fair trade and do not cheat (Bauman \& Skitka, 2012). Employing expectation-confirmation theory, we contend that if an organization fulfills such expectations, their customers will be more attracted, loyal and relate a positive association with such organization. On the basis of above discussion, following hypothesis is proposed:

H1: CSR initiatives are positively related to customer-based brand equity.

\subsection{CSR and customer satisfaction}

Customers feel more satisfied buying products and services of those companies which are engaged in social activities (Luo \& Bhattacharya, 2006). Customers establish strong connection, identity and favorable attitude toward the companies which have shown a good record of CSR (Brown \& Dacin, 1997; Bhattacharya \& Sen, 2004). Another stream of literature suggests that perceived value of products and services trigger customer satisfaction and consequently, customers will derive better perceived value from the product/service that engages in social related causes (Luo 
\& Bhattacharya, 2006). Furthermore, Hsu (2012) concluded that a positive effect on customer satisfaction is generated by company's CSR activities. Employing similar theoretical underpinning as in case of $\mathrm{H} 1$, it is proposed that:

H2: CSR initiatives are positively related to customer satisfaction.

\subsection{Customer satisfaction and customer-based brand equity}

Satisfied customers show a greater level of awareness therefore, they can easily recall the characteristics and different aspects of the brand (Pappu \& Quester, 2006). Image of a brand is based on attributes and benefits customer perceive to derive and the strength of these associations depends on the level of satisfaction (Krishnan, 1996; Pappu \& Quester, 2006). Customer's positive experience with the brand also shape brand image and brand loyalty (Nam, Ekinci, \& Whyatt, 2011).

Previous researches on satisfaction and level of quality have reported a significant positive relationship between the two (e.g. Olsen, 2002; Sivadas \& Baker-Prewitt, 2000). Quality of the product/service is perceived to be good by satisfied customers. The relationship of loyalty and satisfaction has resulted in mixed views in the past with some studies stating a no-to-weak relationship between these variables (Perez \& del Bosque, 2015). Due to the mixed views on customer satisfaction-brand equity relationship, the associative network memory model (Anderson, 1993) which is one of the extensively used models in marketing can be used to explain the relationship of customer satisfaction and customer-based brand equity. Customers store information relating to the brand as nodes in their memory which are connected to one another. For example, if product "X" is one node then its attributes such as "good design", "quality" and "color" represent other nodes which are linked to "X" forming an associative network. If any one of the node in the network is activated it will eventually active the other nodes in the associative memory network. The strength of this association will depend upon the number of times one node has been activated and linked with the other nodes in past (Till \& Shimp, 1998). Thus, it can be logically deduced that the strength of positive association will be higher in satisfied customers. Hsu (2012) concluded that brand equity is affected positively by customer satisfaction. So, in line with above discussion this study proposes that:

H3: Customer satisfaction is positively related to customer-based brand equity.

\subsection{Customer satisfaction as a mediator}

Corporate social responsibility (CSR) affects behavioral outcomes through direct or mediated paths and customer satisfaction is considered as an evaluative outcome of CSR (Brown \& Dacin, 1997; Luo \& Bhattacharya, 2006). CSR may directly and 
indirectly affect the firm performance through various mediating factors (Lee \& Heo, 2009). Customer satisfaction can be thought of that mediating link between CSR and brand equity. Past research has shown customer satisfaction to partially mediate the relationship between CSR and firm market value (Luo \& Bhattacharya, 2006). Hsu (2012) found satisfaction as partial mediator between CSR and brand equity.

Satisfaction is driven from the experience of the customer with the firm and the information customer has in form of corporate associations about the firm (Davies et al. 2002). Customer satisfaction not only includes cognitive component but also emotional response towards a brand (del Bosque $\&$ Martin, 2008; Nam et al. 2011). By showing a responsible behavior, a firm can gain the support of its stakeholders (i.e. customers in this case) that will contribute towards creating a strong and unique brand affiliation (Keller, 1993). It is also believed that positive experiences of customer will enhance their trust on the brand (Kim, Hur \& Yeo, 2015). A firm's strong CSR record can thus lead to enhancement in the level of customer satisfaction that would translate into potential benefits like customer-based brand equity.

As customer satisfaction deals with expectations, therefore, we draw upon the expectation-confirmation theory because it can be a conceptual foundation for explaining such relationships. The theory assumes that expectations coupled with perceived performance lead to post-purchase satisfaction (Oliver, 1980). When a product goes beyond customer's expectations, post purchase satisfaction is increased while if a product does not fulfill the expectations, it results in customer's dissatisfaction (Spreng, MacKenzie, \& Olshavsky, 1996). Drawing upon expectation-confirmation theory, we argue that customers are aware of the social responsibilities of companies. They expect companies to be socially responsible and do not take advantage of innocent customers (Anderson \& Weitz, 1992). Customers' expectations are fulfilled when companies act in socially responsible way. This fulfillment of expectations increases brand loyalty and association which ultimately lead to brand equity because satisfied customers are more likely to repurchase a product (e.g. Cronin \& Taylor, 1992; Dabholkar, Shepherd, \& Thorpe, 2000). From this perspective, responsible social behavior is what customer expects, the more these expectations are fulfilled, the more valuable will be the brand equity (Lai et al. 2010).

In addition, Associative network memory model of Anderson (1993) and Kano, Seraku, Takahashi and Tsuji (1984) model can be used here to explain this relationship. According to the model, product requirements influence customer satisfaction and attractive requirements are not explicitly stated and considered as latent needs but if they are fulfilled they lead to delighted and satisfied customers. Exhibition of social responsibilities can be expressed as a latent need of a customer. CSR therefore, can result in satisfied customers which would in turn drive way for the creation of a 
differential effect of the brand which can be conceptualized on the basis of customer's memory-based association with the brand as discussed earlier.

Therefore, it is expected that customer satisfaction will mediate the relationship between CSR and customer-based brand equity. This discussion of the literature also meets Baron and Kenny (1986) definition of the mediator as variations in CSR accounts for variations in customer satisfaction, variations in customer satisfaction accounts for variations in customer-based brand equity and also CSR relates to customer-based brand equity. So, this study proposes that:

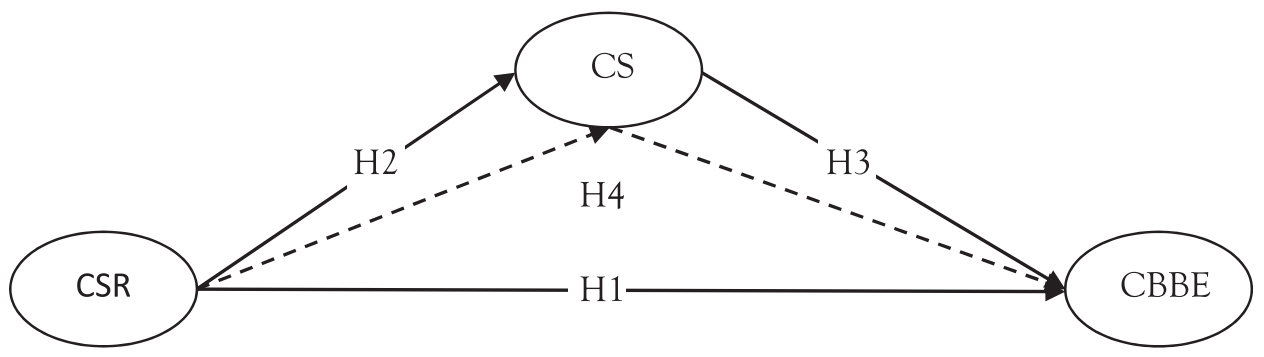

Figure 1: Conceptual Framework

Notes: CSR $=$ Corporate Social Responsibility, CS $=$ Customer Satisfaction, CBBE $=$ Custom er-based brand equity

H4: Customer satisfaction mediates the relationship between CSR and customer-based brand equity.

\section{Methodology}

\subsection{Sample and procedure}

We collected data using quantitative methodology from customers of the wellknown brands of consumer goods and services located in Pakistan. Since this is a causal study therefore, quantitative methodology is appropriate for achieving its aim. Furthermore, quantitative methodology is also appropriate for statistical analysis as well as collection of data from a large sample size (Sekaran \& Bougie, 2010). Five different brands were selected for this purpose. Active involvement in responsible and socially active business as well as promotion of those activities on electronic and print media was the criteria of selection of brands. Both service and manufacturing sectors were included in the study to tap the effects of socially responsible initiatives. Our study included customers of mobile manufacturers, telecom service providers, beverages and consumer goods manufacturers. These organizations hold formal CSR policies, code of ethics, diversity statements and also publish social reports on a reg- 
ular basis. We acquired data from these customers through self-administered paperand-pen questionnaires using convenient sampling technique. For this purpose, we mostly relied on students of universities in and around Islamabad and Rawalpindi. This method was adopted because universities have a large number of students who are consumers of various telecom products, food \& beverages etc. Since English is the official language for communication within organizations in Pakistan, therefore, questionnaire was administered in English language. However, it was ensured that data must be collected from people working on white color positions or studying at university level and having a minimum qualification of intermediate or above. This method of data collection is in line with the previous studies (see Naseer et al. 2016). Volunteer participation and confidentiality of data were promised and maintained. To proceed, hardcopy of questionnaires was distributed to the customers who participated voluntarily.

\subsection{Measures}

Relevant literature provided measurement items for all variables. The questionnaire contained four sections containing separate questions of each construct and demographic information of the respondents. We relied on adopting existing and well established/validated questionnaires from the extant literature for this purpose. For all variables, except demographics, five point Likert scale was used to measure all items where 1 meant strongly disagree and 5 meant strongly agree.

\subsubsection{Corporate social responsibility}

We measured CSR on a four item scale adapted from Lai et al. (2010). Social initiatives related to stakeholders including employees, buyers, community were used as a basis to measure CSR. Examples of these items include "concern with the local community", "concern with environmental protection”, "concern with buyer's benefits" and "participation in social initiatives". Cronbach's alpha of the scale was .68.

\subsubsection{Customer satisfaction}

We used three-item scale by Maxham and Netemeyer (2002) to measure customer satisfaction. Sample item included "I am satisfied with the services the company provides to me". The scale had an alpha-reliability of .77.

\subsubsection{Customer-based brand equity}

We adapted a four dimensional scale to measure brand equity from the study of Lai et al. (2010). It is a 13 item scale assessing all four dimensions which are brand loyalty, perceived quality, brand awareness and association. These items have been 
originally developed by Washburn and Plank (2002) and Yoo and Donth (2001). One characteristic example item for brand loyalty included "Products and services of this brand are my first choice", item for perceived quality included "The likelihood that this brand is reliable is very high", item for brand awareness included "I can recognize

Table 1: Scales Used and Sources

\begin{tabular}{|c|c|c|}
\hline S.No & Scale \& No. of items & Source(s) \\
\hline 1 & Corporate Social Responsibility (4 items) & Lai et al. (2010) \\
\hline 2 & Customer Satisfaction (3 items) & Maxham and Netemeyer (2002) \\
\hline 3 & Customer-based brand equity (13 items) & $\begin{array}{c}\text { Lai et al. (2010) adopted from Washburn } \\
\text { and Plank (2002) and Yoo and Donth } \\
(2001)\end{array}$ \\
\hline
\end{tabular}

this brand among competitive brands" and item for brand association included "I can quickly recall the symbol and logo of this brand". The coefficient of alpha for this scale was .89 .

\section{Results}

\subsection{Descriptive statistics and correlations}

Total number of participants were 225 with a response rate of $90.8 \%$. In our sample, $51.1 \%$ of the respondents were female. The sample included younger population with majority aged between 21-25 years which is indicative of the fact that younger consumers engage more in brand shopping (Pappu \& Quester, 2006). Among them, $16 \%$ of the respondents had their age between $26-30$ years and $12.9 \%$ were aged above 31 years. $78.2 \%$ of the respondents were unmarried. $58.7 \%$ respondents were holding a masters degree, $23.6 \%$ had education up to M.Phil/PhD with the remaining holding either an intermediate or bachelor's/undergraduate degree.

Table 2 reports the means, standard deviations and bivariate correlations and

Table 2: Means, Standard Deviations, Correlations and Reliabilities

\begin{tabular}{|c|c|c|c|c|c|c|c|c|c|}
\hline & Mean & SD & 1 & 2 & 3 & 4 & 5 & 6 & 7 \\
\hline 1.Gender & 1.51 & .50 & - & & & & & & \\
\hline 2.Age & 2.29 & .85 & .00 & - & & & & & \\
\hline $\begin{array}{c}\text { 3.Qualifica- } \\
\text { tion }\end{array}$ & 2.89 & .87 & $.17^{* *}$ & $.18^{* *}$ & - & & & & \\
\hline $\begin{array}{c}\text { 4.Marital } \\
\text { status }\end{array}$ & 1.78 & .41 & .04 & $-.54^{* *}$ & -.01 & - & & & \\
\hline
\end{tabular}




\begin{tabular}{|c|c|c|c|c|c|c|c|c|c|}
\hline 5.CSR & 3.39 & .74 & $.16^{*}$ & .03 & -.02 & -.05 & $(.68)$ & & \\
\hline $\begin{array}{c}\text { 6.Brand } \\
\text { Equity }\end{array}$ & 3.52 & .73 & $.14^{*}$ & -.01 & .07 & -.01 & $.59^{* *}$ & $(.89)$ & \\
\hline $\begin{array}{c}\text { 7.Customer } \\
\text { Satisfaction }\end{array}$ & 3.49 & .92 & $.15^{*}$ &. .03 & .07 & -.03 & $.51^{* *}$ & $.72^{* *}$ & $(.77)$ \\
\hline
\end{tabular}

Note. $\mathrm{N}=225$; Cronbach's alphas presented in parenthesis; CSR=Corporate social responsibility. ${ }^{*} \mathrm{p}<.05,{ }^{* *} \mathrm{p}<.01$

alpha reliabilities of the variables. CSR shows a direct positive correlation with customer-based brand equity $(\mathrm{r}=.59, \mathrm{p}<0.01)$ and customer satisfaction $(\mathrm{r}=.51, \mathrm{p}$ $<0.01)$. Customer satisfaction and customer based brand equity are also positively correlated $(\mathrm{r}=.72, \mathrm{p}<0.01)$.

\subsection{Regression analysis}

In regression analysis, mediation was done (see table 3). Before mediation, mediation rule of Baron and Kenny's (1986) was applied. According to Baron and Kenny, there is need to fulfill three prerequisites to test mediation:

A significant relationship between independent and dependent variable Significant relationship between independent variable and mediator Significant relationship between mediator and dependent variable. To test the first hypothesis, we tested corporate social responsibility (CSR)'s impact on customer-based brand equity. The hypothesis was supported as statistically significant relationship was found between the two $(\beta=.58, p<0.01)$. This suggests that CSR has a positive impact on customer-based brand equity. Second hypothesis was also accepted because CSR was significantly related with customer satisfaction $(\beta=.50, p<0.01)$. Similarly, customer satisfaction was significantly positively related with customer-based brand equity $(\beta=.57, p<0.01)$. These results support the hypothesis 3 .

Thus in alignment with the theory, CSR initiatives exert positive effects on customer satisfaction and customer-based brand equity as shown by the significantly positive beta coefficient values. Customer satisfaction also positively relates to customer-based brand equity. Results show that conditions for mediation have been met (Baron and

Table 3: Main Effects and Mediation Regression Analysis

\begin{tabular}{|l|c|c|c|c|c|c|}
\hline \multirow{2}{*}{ Predictors } & \multicolumn{3}{|c|}{ Customer Satisfaction } & \multicolumn{3}{c|}{ Brand Equity } \\
\cline { 2 - 7 } & $\beta$ & $\mathrm{R}^{2}$ & $\Delta \mathrm{R}^{2}$ & $\beta$ & $\mathrm{R}^{2}$ & $\Delta \mathrm{R}^{2}$ \\
\hline \multicolumn{4}{|c|}{ Main effects: CSR } \\
\hline
\end{tabular}




\begin{tabular}{|c|c|c|c|c|c|c|}
\hline $\begin{array}{l}\text { Step1 Control } \\
\text { variables }\end{array}$ & \multicolumn{3}{|c|}{.02} & \multicolumn{3}{|c|}{.02} \\
\hline Step 2 CSR & $.50^{* *}$ & .27 & $.25^{* *}$ & $.58^{* *}$ & .35 & $.33^{* *}$ \\
\hline \multicolumn{7}{|c|}{ Mediation: Customer satisfaction } \\
\hline Step1 Controls & & & & \multicolumn{3}{|c|}{.02} \\
\hline $\begin{array}{l}\text { Step2 Customer } \\
\text { Satisfaction }\end{array}$ & & & & $.57^{* *}$ & .52 & $.50^{* *}$ \\
\hline Step3 CSR & & & & $.29^{* *}$ & .59 & $.07^{* *}$ \\
\hline
\end{tabular}

Note: $\mathrm{N}=225$; Control variable is gender, ${ }^{* *} \mathrm{p}<.01$

Kenny, 1986). After the fulfillment of three basic conditions, mediation was tested. According to Baron and Kenny, if relationship between independent and dependent variables is insignificant after controlling the mediator than the mediator is a full mediator and complete mediation occurs, showing that mediation is necessary for a particular relationship.

The analysis of mediated regression shows that after the introduction of customer satisfaction as mediator the indirect effects of CSR on customer-based brand equity becomes less (see table 3). Previously $33 \%(\beta=.58, p<0.01)$ of the variations in customer-based brand equity were explained by CSR but with the introduction of customer satisfaction the level of explained variation was reduced to $7 \%(\beta=.29$, $p<0.01$ ). Therefore, sufficient evidence exists about the substantial mediation of customer satisfaction between CSR and customer-based brand equity. These results substantially support the hypothesis 4 .

\section{Conclusion}

\subsection{Discussion \& implications}

During the last few decades, CSR has been the focus of extensive research pertaining to its observed beneficial effects on the firm's financial and market performance, competitiveness and innovation. Due to its increased importance, this study focused on the relationship of CSR and customer-based brand equity and also tests the role of customer satisfaction as mediator. In general, all the hypotheses of the study were supported. The result of the first hypothesis indicates a positive effect of CSR activities undertaken by companies on customer-based brand equity i.e. CSR initiatives increases the value of brand equity which is in line with the past literature (e.g. Hoeffler \& Keller, 2002; Bhattacharya \& Sen, 2004). These results show that company's social behavior towards customer and community increases the value of company in the mind of customer. In this case, customer develops a feeling that com- 
pany is caring for them, resulting in a good image of the company. With this finding, we have achieved our first objective.

In addition, implementation of CSR policies helps maintaining a trusting relationship between company and customer because the perception of CSR provokes positive brand association, increase perceived quality of products, enhances brand loyalty and satisfaction (Lai et al. 2010). When buyers perceive that company is promoting ethical practices, it develops an emotional feeling in the minds of customers toward brands. Thus, CSR activities are necessary to build a connection with the customer since these activities generate a feeling of being valued. One important implication from this study is that CSR does play a role in shaping consumers' behaviors and that consumers also take notice of the social behaviors of the companies. Therefore, this study implicates that CSR can be a source of competitive advantage should the organizations adopt and communicate CSR practices with care (Ahmad, Donia \& Shahzad, 2018).

The result of the second hypothesis shows that a strong CSR record of a company results in the generation of satisfied customers. This finding is also aligned with the study of Luo and Bhattacharya (2006) which shows a positive effect of CSR on consumer satisfaction as it results in better evaluation of the company by the customers in terms of perceived value. When customers perceive company as socially responsible, they feel more satisfaction towards their brand and company because customer satisfaction is a bridge that links CSR actions to a brand by a psychological mechanism involving cognitive, affective and behavioral response of the customer (Anderson, 1993). Objective two of the study was achieved with this result by studying the direct impact of corporate social responsibility on customer satisfaction. For the third hypothesis, the results indicate that the customer-based brand equity varies according to the level of satisfaction. Pappu and Quester (2006) also reached to similar conclusion. This means that higher level of customer satisfaction indicates higher level of fulfillment of customer expectations which consequently enhance brand equity in customers' minds. This result also achieves the third objective of the study.

Similarly, another theoretical implication of this study is providing a reasonably good support for customer satisfaction as a mediator in the relationship between CSR and brand equity. Past studies have also stressed on the exploring the underlying mechanisms through which CSR leads to important outcomes (Glavas, 2016). The results of this study therefore, suggest that the reduction in the variation explained considering the indirect effects of CSR supports the substantial mediating role of customer satisfaction which implies that if the organization focuses on generating satisfied customers through responsible activities they can increase the equity value of their brands. Therefore, it can be said that customer satisfaction is a strong but not 
fully mediated path through which CSR shows its effect on customer-based brand equity. Furthermore, the underlying theoretical mechanism through which CSR affects various outcomes is another novel contribution of this study. Relying on the expectation-confirmation theory, we concluded that customers expect that organization will behave responsibility and do not cheat them, thereby, providing quality products and services. When companies fulfill this responsibility, it leads towards increased satisfaction and consequently increased customer-based brand equity. Investigating the mediating role of customer satisfaction achieves our objective four of this study.

Culture can also influence the importance assigned to CSR because the reported study was conducted in Pakistan where the concept of CSR is still in its nascent stage. It has been observed that individualistic societies emphasize more on the economic performance rather than social welfare activities whereas collectivistic cultures attach more importance to recognition of responsibilities towards the betterment of the society (Maignan \& Ferrell, 2003; Waldman et al. 2006). As the culture of Pakistan is collectivistic (Hofstede, 1984), therefore, people in Pakistan emphasize on the social activities and when they feel that companies are socially responsible, they feel more value and satisfaction with a particular brand. Therefore, evidence from a collectivist culture regarding the CSR and its role in shaping customers' behaviors i.e. brand-equity, is another novel contribution of this study and therefore, achieves objective five of this study.

\subsection{Managerial implications}

The following implications for managers can be noted from this study. CSR activities can be beneficial for the company in the long run which can improve customer-based brand equity as well as satisfaction thereby generating huge profits for the company. For this purpose, development of CSR education is important to spread awareness of the trend (Kim et al. 2015; Matten \& Moon, 2004). The managers should make the CSR policies more reliable in the eyes of customers because satisfied customers will in turn yield benefits for the company by driving way for the creation of differential effects of the brands. Therefore, mangers should focus on the potential gains while allocating budgets for the measurement of satisfaction in their research budgets since satisfaction play a key role (Pappu \& Quester, 2006). Furthermore, companies need to implement the effective CSR strategies by considering their benefits because right CSR strategies congregate between social and economic goals (Lindgreen \& Swaen, 2010). Likewise, several training programs can be arranged for managers to enhance their knowledge regarding CSR and its role in shaping customers' behaviors and how to develop effective CSR strategies and maximize on its leverages. Another key managerial implication is the communication of CSR contributions to 
the stakeholders. Past studies have found that people keep a close eye on the intentions of organizations' engagement in CSR practices (Ahmad et al. 2018). Therefore, managers must ensure the they adopt such communications strategies which transmit a message of genuine contributions and not just green-washing.

\subsection{Limitations and future research}

Although findings of our study provide a valuable extension in existing knowledge, however, future research can address some of the issues. First, the current study has tapped the relationship from the perspective of only one stakeholders i.e. customers. Future research can investigate the relationship from other stakeholders' perspective. Second limitation is the slightly lower reliability of CSR $(\square=.68)$. Third important limitation to be addressed is the sample size. This study has used 225 responses which can affect the generalizability of our findings. Therefore, future researchers are suggested to address this issue by replicating this study with large sample size. Previous studies showed that CSR is a multidimensional construct, but in this study we focused on a single dimension i.e. social. Thus future researchers are encouraged to check the effects of all dimensions on customer-based brand equity as well on other outcomes. Finally, this study was done using cross sectional data, but in future, longitudinal data can be gathered to increase the generalizability of findings.

\section{References}

Aaker, D.A. (1991). Managing brand equity. New York: The Free Press.

Ailawadi, K.L., Lehmann, D.R. \& Neslin S. A. (2003). Revenue premium as an outcome measure of brand equity. Journal of Marketing, 67, 1-17.

Ahmad, I. (2017). Understanding internal, external and relational attributions in reaction to corporate social responsibility. Business Eु Economic Review, 9(4), 49-64.

Ahmad, I., Donai, M., \& Shahzead, K. (2018). Impact of corporate social responsibility attributions on employees' creative performance: The mediating role of psychological safety, Ethics $\mathcal{E}$ Behavior, DOI: $10.1080 / 10508422.2018 .1501566$

Anderson, J. R. (1993). The adaptive character of thought. Hillsdale, NJ: Lawrence Erlbaum Associates.

Anderson, E., \& Weitz, B. (1992). The use of pledges to build and sustain commitment in distribution channels. Journal of Marketing Research, 29, 18-34.

Baron, R. M. \& Kenny, D. A. (1986). The moderator-mediator variable distinction in social psychological research: Conceptual, strategic, and statistical consideration. Journal of Personality and Social Psychology, 51, 1173-1182.

Bauman, C.W., \& Skitka, L.J. (2012). Corporate social responsibility as a source of employee satisfaction. 
Research in Organizational Behavior, 32, 63-86.

Bhattacharya, C.B. \& Sen S. (2004). Doing better at doing good: When, why and how consumers respond to social initiatives. California Management Review, 47, 9-25.

Blumenthal, D. \& Bergstrom, A.J. (2003) Brand councils that care: Towards the convergence of branding and corporate social responsibility. Journal of Brand Management, 10, 327-341.

Brady, M. K. \& Robertson, C. J. (2001). Searching for a consensus on the antecedent role of service quality and satisfaction: An exploratory cross-national study. Journal of Business Research, 51, 53-60.

Brown, T. J. \& Dacin, P.A. (1997). The company and the product: Corporate associations and consumer product responses. Journal of Marketing, 61, 68-84.

Brown, T. J. (1998). Corporate associations in marketing: Antecedents and consequences. Corporate Reputation Review, 1(3), 215-233.

Carroll, A. B. (1991). The pyramid of corporate social responsibility: Toward the moral management of organizational stakeholders. Business Horizons, 34, 39-49.

Cronin, J. J, Taylor, S. A. (1992). Measuring service quality: A reexamination and extension. Journal of Marketing, 56, 55-68.

Dabholkar, P. A, Shepherd, C. D., \& Thorpe, D. I. (2000). A comprehensive framework for service quality: an investigation of critical conceptual and measurement issues through a longitudinal study. Journal of Retailing, 76, 139-173.

Davies, G., Chun, R., Da Silva, R. V., \& Roper, S. (2002). Corporate reputation and competitiveness. London: Routledge.

Deng, X., \& Xu, Y. (2017). Consumers' responses to corporate social responsibility initiatives: The mediating role of consumer-company identification. Journal of Business Ethics, 142, 515-526.

del Bosque I. R. \& Martin, H. S. (2008). Tourist satisfaction a cognitive-affective model. Annals of Tourism Research, 35, 551-573.

Donio, J., Massari, P. \& Passinate, G. (2006). Customer satisfaction and loyalty in a digital environment: An empirical test. Journal of Consumer Marketing, 23, 445-457.

Drazin, R. \& Schoonhoven, C. B. (1996). Community, population, and organization effects on innovation: A multilevel perspective. The Academy of Management Journal, 39, 1065-1083.

Du, S., Bhattacharya, C. B. \& Sen, S. (2010). Maximizing business returns to corporate social responsibility (CSR): The role of CSR communication. International Journal of Management Reviews, 12, 8-19.

Fatima, M., Rahman, Z., \& Khan, I. (2015). Building company reputation and brand equity through CSR: The mediating role of trust. International Journal of Bank Marketing, 33(6), 840-856.

Ferrell, O.C. (2004). Business ethics and customer stakeholders. Academy of Management, 18, 126-129. 
Gatti, L., Caruana, A., \& Shenota, I. (2012). The role of corporate social responsibility, perceived quality and corporate reputation on purchase intention: Implications for brand management. Journal of Brand Management, 20, 65-76.

Glavas, A. (2016). Corporate social responsibility and organizational psychology: An integrative review. Frontiers in Psychology, DOI:10.3389/fpsyg.2016.00144

Green, T. \& Peloza, J. (2011). How does corporate social responsibility create value for consumers? Journal of Consumer Marketing, 28, 48-56.

Gruca, T. S. \& Rego, L. L. (2005). Customer satisfaction, cash flow and shareholder value. Journal of Marketing, 69, 115-130.

Guzmán, F., \& Davis, D. (2017). The impact of corporate social responsibility on brand equity: consumer responses to two types of fit. Journal of Product E Brand Management, 26(5), 435-446.

Halstead, D. (1999). The use of comparison standards in customer satisfaction research and management: A review. Journal of Marketing Theory E Practice, 7(3), 13-26.

Hoeffler, S. \& Keller, K.L. (2002). Building brand equity through corporate social marketing. Journal of Public Policy and Marketing, 21, 78-89.

Hofstede, G. (1984). Cultural Dimensions in Management and Planning. Asia Pacific Journal of Management, 1, 81-99.

Holt, D. B, Quelch, J. A. \& Taylor, E. L. (2004). How global brands compete. Harvard Business Review, $82,68-75$.

Hsu, K-T. (2012). The advertising effects of corporate social responsibility on corporate reputation and brand equity: Evidence from the life insurance industry in Taiwan. Journal of Business Ethics, 109, 189-201.

Hur, W., Kim, H., \& Woo, J. (2014). How CSR leads to corporate brand equity: Mediating mechanism of corporate brand credibility and reputation. Journal of Business Ethics, 125, 75-86.

Kano, N., Seraku, N., Takahashi, F., \& Tsuji, S. (1984). Attractive quality and must-be quality. The Journal of the Japanese Society for Quality Control, 14, 39-48.

Keller, K. L. (1993). Conceptualizing, measuring and managing customer-based brand equity. Journal of Marketing, 57, 1-22.

Khan, A. A. (2012). Corporate social responsibility: Studying the sugar production process in Pakistan. Oxfam Novib, Bangalore. Retrieved from: http://www.sdpi.org/ research_programme/researchproject-53-30-56.html

Kiessling, T., Isaksson, L., \& Yasar, B. (2016). Market orientation and CSR: Performance implications. Journal of Business Ethics, 137, 269-284. 
Kim, H., Hur, W., \& Yeo, J. (2015). Corporate brand trust as mediator in the relationship between consumer perception of CSR, corporate hypocrisy, and corporate reputation. Sustainability, 7, 3683-3694.

Krishnan, H. S. (1996). Characteristics of memory associations: A consumer based brand equity perspective. International Journal of Research in Marketing, 13, 389-405.

Lai, S. L., Chiu, C. J., Yang, C. F. \& Pai, D. C. (2010). The effects of corporate social responsibility on brand performance: The mediating effect of industrial brand equity and corporate reputation. Journal of Business Ethics, 95, 457- 469.

Lassar, W., Mittal, B., \& Sharma, A. (1995). Measuring customer-based brand equity. Journal of Consumer Marketing, 12, 11-19.

Lee, S. \& Heo, C. Y. (2009). Corporate social responsibility and customer satisfaction among US publicly traded hotels and restaurants. International Journal of Hospitality Management, 28, 635-637.

Lindgreen, A. \& Swaen, V. (2010). Corporate social responsibility. International Journal of Management Reviews, 12, 1-7.

Luetkenhorst, W. (2004). Corporate social responsibility and the development agenda: The case for actively involving small and medium enterprises. Intereconomics, 39, 157-166.

Luo, X. \& Bhattacharya, C. B. (2006). Corporate social responsibility, customer satisfaction and market value. Journal of Marketing, 70, 1-18.

Maignan, I. \& Ferrell, O. C. (2003). Nature of corporate responsibilities: perspectives from American, French and German consumers. Journal of Business Research, 56, 55-67.

Matten, D. \& Moon, J. (2004). Corporate social responsibility education in Europe. Journal of Business Ethics, 54, 323-337.

Matten, D., \& Moon, J. (2008). Implicit" and "explicit" CSR: A conceptual framework for a comparative understanding of corporate social responsibility. Academy of Management Review, 3, 404-424.

Maxham, J. G. \& Netemeyer, R.G. (2002). A longitudinal study of complaining customers' evaluations of multiple service failures and recovery efforts. Journal of Marketing, 66, 57-71.

McGuire, J. B., Sundgren, A., \& Schneeweis, T. (1988). Corporate social responsibility and firm financial performance. Academy of Management, 31, 854-872.

McWilliams, A., Siegel, D. S., \& Wright, P. M. (2006). Corporate social responsibility: strategic implications. Journal of Management Studies, 43, 1-18.

Miller, D. \& Merrilees, B. (2013). Linking retailer corporate brand and environmental sustainability practices. Journal of Product and Brand Management, 22(7), 437-443.

Nam, J., Ekinci, Y., \& Whyatt, J. (2011). Brand equity, brand loyalty and customer satisfaction. Annals of Tourism Research, 38, 1009-1030. 
Narwal, M. \& Singh, R. (2013). Corporate social responsibility practices in India: A comparative study of MNCs and Indian companies. Social Responsibility Journal, 9, 465-478.

Naseer, S., Raja, U., Syed, F., Donai, B. L. M., \& Darr, W. (2016). Perils of being close to a bad leader in a bad environment: Exploring the combined effects of despotic leadership, leader member exchange, and perceived organizational politics on behaviors. The Leadership Quarterly, 27, 14-33.

Oliver, R. L. (1980). A cognitive model of the antecedents and consequences of satisfaction decisions. Journal of Marketing Research, 17, 460-469.

Oliver, R. L. (1997). A behavioral perspective on the consumer. New York, NY: McGraw-Hill.

Olsen, S. O. (2002). Comparative evaluation and the relationship between quality, satisfaction, and repurchase loyalty. Journal of the Academy of Marketing Science, 30, 240-249.

Pappu, R. \& Quester, P. (2006). Does customer satisfaction lead to improved brand equity? An empirical examination of two categories of retail brands. Journal of Product $\mathcal{E}$ Brand Management, 15, 4-14.

Perez, A., \& del Bosque, I. R. (2015). An integrated framework to understand how CSR affects customer loyalty through identification, emotions and satisfaction. Journal of Business Ethics, 129, 571-584.

Rayapura, A. (2014). New Nielsen study says consumers are ready to pay more for social responsibility. Available at: www.sustainablebrands.com/news_and_views/stakeholder_trends_insights/aarthi_rayapura/ new_nielsen_study_says_consumers_are_read (accessed 18 March 2018).

Rust, R. T., Zeithaml, V. A., \& Lemon, K. N. (2000). Driving customer equity. New York, NY: Free Press.

Salmones, M. G., Crespo, A. H., \& del Bosque, I. R. (2005). Influence of corporate social responsibility on loyalty and valuation of services. Journal of Business Ethics, 61, 369-385.

Sekaran, U., \& Bougie, R. (2010). Research methods for business: A skill building approach (5th ed.). West Sussex, UK: John Wiley \& Sons Ltd.

Sen, S., Du, S., \& Bhattacharya, C. B. (2016). Corporate social responsibility: a consumer psychology perspective. Current Opinion in Psychology, 10, 70-75.

Sen, S. \& Bhattacharya, C. B. (2001). Does doing good always lead to doing better? Consumer reactions to corporate social responsibility. Journal of Marketing Research, 38, 225-243.

Securities and Exchange Commission of Pakistan (2013). Corporate Social Responsibility Voluntary guidelines 2103. http://www.secp.gov.pk/notification/pdf/2013/VoluntaryGuidelinesforCSR_201 pdf (assessed 10 March, 2013).

Sivadas, E. \& Baker-Prewitt, F.L. (2000). An examination of the relationship between service quality, customer satisfaction, and store loyalty. International Journal of Retail $\mathcal{E}$ Distribution Management, 28, 73-82. 
Spector, A. J. (1956). Expectations, fulfillment and morale. Journal of Abnormal and Social Psychology, $52,51-56$

Spreng, R. A., MacKenzie, S. B., \& Olshavsky, R. W. (1996). A reexamination of the determinants of consumer satisfaction. Journal of Marketing, 60, 15-32.

Swait, J., Erdem, T., Louviere, J., \& Dubelaar, C. (1993). The equalization price: A measure of consumer perceived brand equity. International Journal of Research in Marketing, 10, 23-45.

Till, B. D. \& Shimp, T. A. (1998). Endorsers in advertising: Ahe case of negative celebrity information. Journal of Advertising, 27, 67-82.

Torres, A., Bijmolt, T. H. A., Tribo, J. A., \& Verhoef, P. (2012). Generating global brand equity through corporate social responsibility to key stakeholders. International Journal of Research in Marketing, 29, $13-24$.

van Rekom, J., Berens, G., \& van Halderen, M. (2013). Corporate social responsibility: Playing to win, or playing not to lose \& quest; Doing good by increasing the social benefits of a company's core activities. Journal of Brand Management, 20, 800-814.

Waldman, D. A., de Luque, M.S., Washburn, N., \& House, R.J. (2006). Cultural and leadership predictors of corporate social responsibility values of top management: A global study of 15 countries. Journal of International Business Studies, 37, 823-837.

Walsh, G. \& Bartikowski, B. (2012). Exploring corporate ability and social responsibility associations as antecedents of customer satisfaction cross-culturally. Journal of Business Research, DOI:10.1016/j. jbusres.2011.12.022.

Wang, H. M. D. (2010). Corporate social performance and financial-based brand equity. Journal of Product E Brand Management, 19, 335-345.

Washburn, J. H. \& Plank, R.E. (2002). Measuring brand Equity: an evaluation of a consumer based brand equity scale. Journal of Marketing Theory and Practice, 10, 46-61.

Wood, D. J. (1991). Corporate social performance revisited. Academy of Management Review, 16, 691-718.

Yoo, B. \& Donthu, N. (2001.) Developing and validating a multi-dimensional consumer based brand equity scale. Journal of Business Research, 52, 1-4.

Zeithaml, V. A. (1988). Consumer perception of price, quality and value: a means-end model and synthesis of evidence. Journal of Marketing, 52, 2-22.

Zeithaml, V.A. \& Bitner, M.J. (2000). Services Marketing. New York, NY: McGraw Hill. 